Original Research Article

\title{
Comparative evaluation of anti-diabetic activity of fresh juice and ethanolic extract of Sunderban mangrove Rhizophora mucronata Lam. leaves in animal model
}

\author{
Anjan Adhikari ${ }^{1 *}$, Moumita Ray ${ }^{1}$, Tapas K. Sur ${ }^{2}$, Sharmistha Biswas ${ }^{3}$, Anup K. Das ${ }^{1}$
}

${ }^{1}$ Department of Pharmacology,

R. G. Kar Medical College, 1-

Kshudiram Bose Sarani, Kolkata 700004, West Bengal, India

${ }^{2}$ Department of Pharmacology, Institute of Post Graduate

Medical Education and

Research, 244, A.J.C. Bose

Road, Kolkata 700020, West

Bengal, India

${ }^{3}$ Department of Anatomy, Malda Medical College, Englishbazar, Malda 732101, West Bengal, India

Received: 25 June 2017

Accepted: 24 July 2017

\section{*Correspondence to:}

Dr. Anjan Adhikari,

Email: dradhikarianjankolkata

@gmail.com

Copyright: (C) the author(s), publisher and licensee Medip Academy. This is an openaccess article distributed under the terms of the Creative Commons Attribution NonCommercial License, which permits unrestricted noncommercial use, distribution, and reproduction in any medium, provided the original work is properly cited.

\begin{abstract}
Background: Mangrove flora possess compounds with potential medicinal values with unique bioactive components. Traditionally Rhizophora mucronata, a mangrove has been used extensively for the treatment of diabetes. Studies revealed that, the leaves of Rhizophora (Bhora) had promising anti-diabetic action in rat model.

Methods: A comparative analysis of the anti-diabetic action of fresh juice and ethanolic extract of Rhizophora mucronata leaves was carried out in Streptozotocin induced diabetic model and the different biochemical parameters were evaluated.

Results: Present research explored a comparative analysis of the anti-diabetic action of fresh juice and ethanolic extract of leaves of Rhizophora mucronata Lam. in Streptozotocin induced diabetic model. The ethanolic extract showed more potent effect in lowering the elevated blood sugar in the diabetic rats, $200 \mathrm{mg} / \mathrm{kg}$ was the most effective dose for both the extracts. The ethanol extract was more beneficial having potent lipid lowering action along with antihyperglycemic property.

Conclusions: This supports the scientific validation for using Rhizophora mucronata leaves in the treatment of diabetes as traditional folk medicine. Identification of the bioactive molecule is under process.
\end{abstract}

Keywords: Anti-oxidant, Diabetes, Ethanol extract, Mangrove, Rhizophora mucronata

\section{INTRODUCTION}

Diabetes is a metabolic disorder consisting of several physiological changes due to chronic hyperglycemia. It affects the glucose transporters, insensitivity of several tissues (skeletal muscle, liver, kidney and adipose tissue) to insulin action leading to insulin resistance, weaker glucose utilization of body etc. ${ }^{1}$ Though remarkable progress achieved in the management of diabetes mellitus using synthetic drugs, still management of diabetes and its 
complication is an unsolved problem. Recently there has been a growing interest in herbal remedies, which are effective, produce minimal or no side effects in clinical experience, and are of relatively low cost, as compared to oral synthetic hypoglycemic agents. ${ }^{2}$ Mangroves are one of the medicinally important plants produce several phytocompounds or secondary metabolites having significant pharmacological properties and are being used traditionally for treatment of several ailments. ${ }^{3,4}$ Rhizophora mucronata is a mangrove (family Rhizophoraceae), commonly known as "red mangrove", used as traditional medicine in the treatment of diarrhea, dysentery, blood in urine, fever, angina, diabetes, hematuria, and hemorrhage. ${ }^{5}$ In South Asian countries together with India, the leaves of $R$. mucronata are being used traditionally for the remedy of diabetes. ${ }^{6,7}$ It is abundantly found on the coastal region. $R$. mucronata $\mathrm{L}$. leaves showed the presence of a good amount of polyphenols, like flavonoid, tannin, glycoside, phenolic compounds. ${ }^{8,9}$

The fresh juice of $R$. mucronata L. leaves significantly reduced blood glucose concentration in Alloxan induced diabetic rats and thereby posesses anti-hyperglycemic action. ${ }^{10}$ Research from Bangladesh revealed the ethanol extract of Rhizophora mucornata leaves has significant dose dependant anti-diabetic effects. ${ }^{11}$ Recent study reported the anti-diabetic action of hydro-methanolic and hydro-ethanolic extract of $R$ mucronata (Sundarban Mangrove) leaves in diabetes model. ${ }^{12,13}$ Hence, the present study has undertaken to explore the comparative analysis between fresh juice and ethanolic extract of the leaves of Rhizophora mucronata Lam. in diabetic rat model. Glibenclamide was used as standard drug in this study.

\section{METHODS}

\section{Collection of plant material and identification}

Rhizophora mucronata leaves were collected from Sunderban, West Bengal, India, in the month of October 2013. The leaves were authenticated from Botanical Survey of India, Howrah, West Bengal (CNH/55/2013/Tech. II/19 dated 02.12.2013) and a voucher specimen has been preserved. The fresh leaves were washed with distilled water.

\section{Extraction of leaves of plant material}

Fresh Rhizophora mucronata Lam. leaves were divided into two groups. Leaves from one group were washed well with distilled water and cut into small pieces. A smooth paste from the leaves was made with mixer grinder. The fresh juice was squeezed out from the paste and the extract was stored well in a tight container for further use. The leaves from another group were shade-dried, pulverized into coarse powder and extracted with ethanol in soxhlet apparatus. Thereafter, the solvent was removed under reduced pressure and the extract was dried.

\section{Animals}

Wistar albino rats of both sexes weighing 150-200gm were used for this study. The animals were kept in the animal house, maintaining standard condition and fed with proper diet and water ad libitum. The animal experiments were conducted in accordance with the accepted principles for laboratory animal use and care (CPCSEA).

\section{In-vivo anti-diabetic study in streptozotocin induced diabetic model}

Streptozotocin (STZ) was dissolved in ice-cold citrate buffer (0.1 M, pH 4.5) and injected intravenously at the dose of $60 \mathrm{mg} / \mathrm{kg}$ in rats (except normal control). ${ }^{14,15}$ The diabetic state (fasting blood glucose $>180 \mathrm{mg} / \mathrm{dl}$ ) was confirmed 3 days after STZ injection. The diabetic rats were randomly grouped in nine groups as described in Table 1.

\section{Table 1: Group distribution and treatment of experimental animals.}

\begin{tabular}{|c|c|}
\hline Groups & Treatment \\
\hline $\begin{array}{l}\text { Group I: Untreated/ } \\
\text { Negative control }\end{array}$ & $\begin{array}{l}\text { Only distilled water } \\
0.1 \mathrm{ml} / \mathrm{kg} \text {, orally }\end{array}$ \\
\hline $\begin{array}{l}\text { Group II: } \\
\text { Diabetic/Positive control }\end{array}$ & $\begin{array}{l}\text { STZ induced, distilled } \\
\text { water } 0.1 \mathrm{ml} / \mathrm{kg} \text {, orally }\end{array}$ \\
\hline $\begin{array}{l}\text { Group III: } \\
\text { Glibenclamide }\end{array}$ & $\begin{array}{l}\text { STZ induced, } \\
\text { Glibenclamide } 10 \mathrm{mg} / \mathrm{kg} \text {, } \\
\text { orally }\end{array}$ \\
\hline $\begin{array}{l}\text { Group IV: RMJ } \\
100 \mathrm{mg} / \mathrm{kg}\end{array}$ & $\begin{array}{l}\text { STZ induced, RMJ } \\
100 \mathrm{mg} / \mathrm{kg}, \text { orally }\end{array}$ \\
\hline $\begin{array}{l}\text { Group V: RMJ } \\
\text { 200mg/kg }\end{array}$ & $\begin{array}{l}\text { STZ induced, RMJ } \\
200 \mathrm{mg} / \mathrm{kg} \text {, orally }\end{array}$ \\
\hline $\begin{array}{l}\text { Group VI: RMJ } \\
\text { 400mg/kg }\end{array}$ & $\begin{array}{l}\text { STZ induced, RMJ } \\
400 \mathrm{mg} / \mathrm{kg} \text {, orally }\end{array}$ \\
\hline $\begin{array}{l}\text { Group VII: RME } \\
100 \mathrm{mg} / \mathrm{kg}\end{array}$ & $\begin{array}{l}\text { STZ induced, RME } \\
100 \mathrm{mg} / \mathrm{kg} \text {, orally }\end{array}$ \\
\hline $\begin{array}{l}\text { Group VIII: RME } \\
\text { 200mg/kg }\end{array}$ & $\begin{array}{l}\text { STZ induced, RME } \\
200 \mathrm{mg} / \mathrm{kg} \text {, orally }\end{array}$ \\
\hline $\begin{array}{l}\text { Group IX: RME } \\
\text { 400mg/kg }\end{array}$ & $\begin{array}{l}\text { STZ induced, RME } \\
400 \mathrm{mg} / \mathrm{kg} \text {, orally }\end{array}$ \\
\hline
\end{tabular}

The dose was selected according to acute toxicity study and previously evaluated pilot study on hypoglycemic action in rats. The treatment regimen was continued once daily dose for 28 days as mentioned above. Thereafter all animals were sacrificed under deep anesthesia and blood was withdrawn.

\section{Statistical analysis}

In present study all data were expressed as mean \pm SEM. The statistical analysis was done by one-way analysis of variance (ANOVA), followed by Dunnet test. The 
statistical software package used for analysis was statistical package for the social sciences (SPSS 15).

\section{RESULTS}

\section{Effect of Rhizophora mucronata extracts on blood glucose profile}

Rhizophora mucronata Lam. leaves fresh juice (RMJ) and ethanolic extract (RME) both possess anti-hyperglycaemic effect by lowering the elevated blood glucose level in the Streptozotocin induced diabetic model in rats (Figure 1). The most significant anti-hyperglycaemic activity was found in the dose $200 \mathrm{mg} / \mathrm{kg}$ body weight for both the extracts in comparison to the diabetic control rats. The ethanolic extract showed more potent blood sugar lowering potentialities in Streptozotocin induced diabetic model among the two extracts.

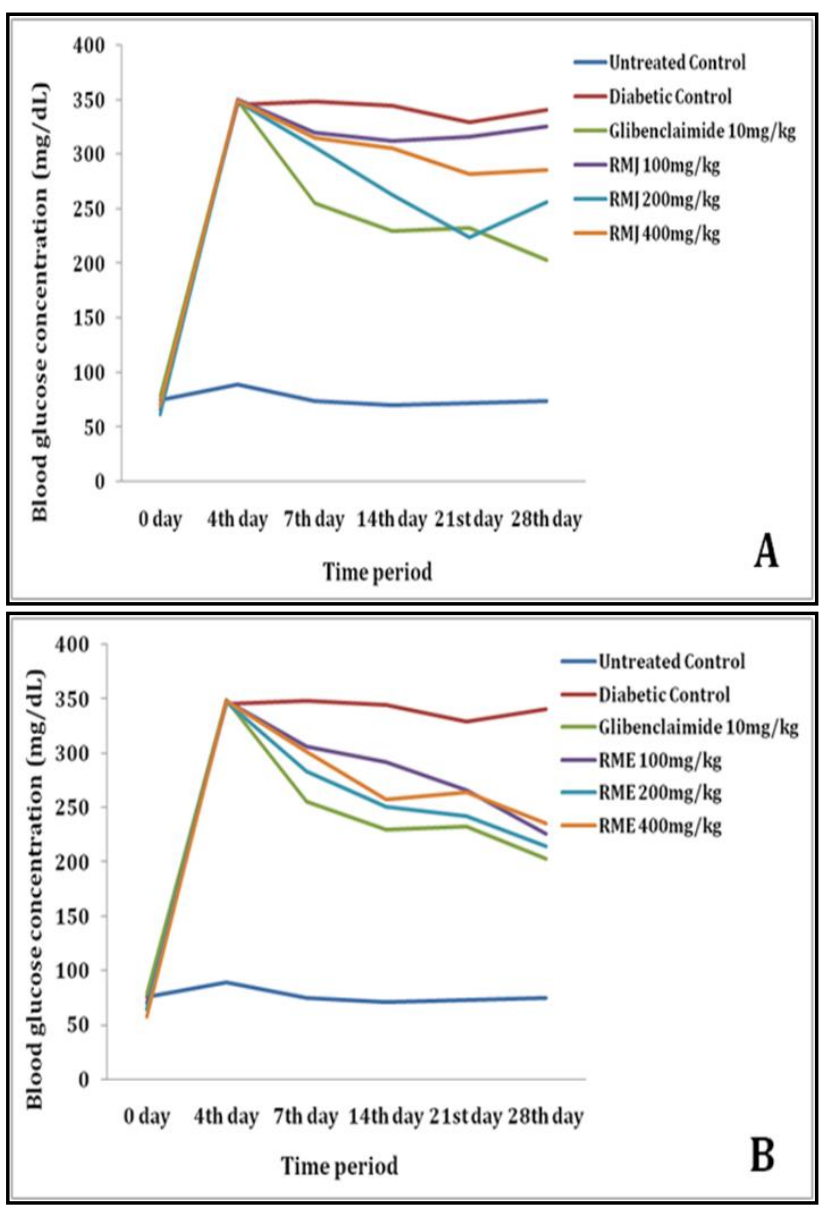

Figure 1: The anti-hyperglycaemic effect in Streptozotocin induced diabetic rats. Blood glucose profile of untreated normal control, diabetic control, standard drug Glibenclamide $10 \mathrm{mg} / \mathrm{kg}$ and different groups treated with fresh juice of the leaves of Rhizophora mucronata (RMJ) (A.) and with ethanol extract (RME) (B.) Data was interpreted as Mean \pm S.E.M ( $n=6$ for each group). Statistical analysis was done by one way ANOVA followed by Dunnett test $(\mathbf{p}<0.05)$
The RMJ at $200 \mathrm{mg} / \mathrm{kg}$ dose reduced the blood glucose level by $24.706 \%$ whereas RME at $200 \mathrm{mg} / \mathrm{kg}$ dose reduced the blood glucose level by $37.059 \%$, which is more similar to that of the standard drug Glibelclamide which showed $40.294 \%$ reduction in blood glucose level (Table 2).

Table 2: Inhibition of blood glucose level (in \%) in different treated groups comparing with the diabetic control on $28^{\text {th }}$ day of the Streptozotocin diabetes model.

\begin{tabular}{|c|c|c|c|}
\hline Groups & \multicolumn{3}{|c|}{$\begin{array}{l}\text { Inhibition in blood glucose level in } \\
\text { comparison with the diabetic control } \\
\text { rats }\end{array}$} \\
\hline $\begin{array}{l}\text { Glibenclami } \\
\text { de } 10 \mathrm{mg} / \mathrm{kg}\end{array}$ & \multicolumn{3}{|l|}{$40.294 \%$} \\
\hline \multicolumn{2}{|c|}{$\begin{array}{l}\text { Rhizophora mucronata } \\
\text { leaves juice (RMJ) }\end{array}$} & \multicolumn{2}{|c|}{$\begin{array}{l}\text { Rhizophora mucronata } \\
\text { leaves ethanol extract (RME) }\end{array}$} \\
\hline $\begin{array}{l}\text { RMJ } \\
100 \mathrm{mg} / \mathrm{kg}\end{array}$ & $4.412 \%$ & $\begin{array}{l}\text { RME } \\
100 \mathrm{mg} / \mathrm{kg}\end{array}$ & $33.529 \%$ \\
\hline $\begin{array}{l}\text { RMJ } \\
200 \mathrm{mg} / \mathrm{kg}\end{array}$ & $\begin{array}{l}24.706 \\
\%\end{array}$ & $\begin{array}{l}\text { RME } \\
200 \mathrm{mg} / \mathrm{kg}\end{array}$ & $37.059 \%$ \\
\hline $\begin{array}{l}\text { RMJ } \\
400 \mathrm{mg} / \mathrm{kg}\end{array}$ & $\begin{array}{l}16.176 \\
\%\end{array}$ & $\begin{array}{l}\text { RME } \\
400 \mathrm{mg} / \mathrm{kg}\end{array}$ & $30.882 \%$ \\
\hline
\end{tabular}

Data was interpreted as Mean \pm S.E.M ( $n=6$ for each group). Statistical analysis was done by one way ANOVA followed by Dunnett test $(\mathrm{p}<0.05)$.

\section{Effect of Rhizophora mucronata extracts on body weight}

It is very interesting to note that, STZ has been reported to reduce body weight in animals, which was observed in the present study also. Both the fresh juice of the leaves of Rhizophora mucronata (RMJ) and the ethanol extract (RME) restore the body weights of the rats during the study period and maintained good health. The ethanolic extract of $R$. mucronata leaves $(100 \mathrm{mg} / \mathrm{kg}$ and $200 \mathrm{mg} / \mathrm{kg}$ ) revealed profound anti-hyperglycemic effect and maintained their body weight like healthy control rats in a dose dependent manner when administered for 4 weeks. Present study revealed that the ethanolic extract showed more potent effect in lowering the elevated blood sugar in the diabetic rats, $200 \mathrm{mg} / \mathrm{kg}$ was the most effective dose for both the extracts. Therefore, further biochemical parameters were compared between these dose treated groups only for the both extracts.

\section{Glucose concentration analysis in urine}

The urine analysis of different group of rats on $28^{\text {th }}$ day of treatment showed the glucose concentration present in rat urine (Figure 2). Glucose content in urine sample of the diabetic control rats was $1 \mathrm{gm} / \mathrm{dl}(\%)$ whereas for the normoglycemic normal group of rats it was found to be negative. In the test group treated with RME it was $1 / 4^{\text {th }}$ or $0.25 \mathrm{~g} / \mathrm{dL}(\%)$ similar as the standard drug treated rats, for the RMJ treated groups it was $1 / 2^{\text {th }}$ i.e. $0.5 \mathrm{gm} / \mathrm{dl}(\%)$. 

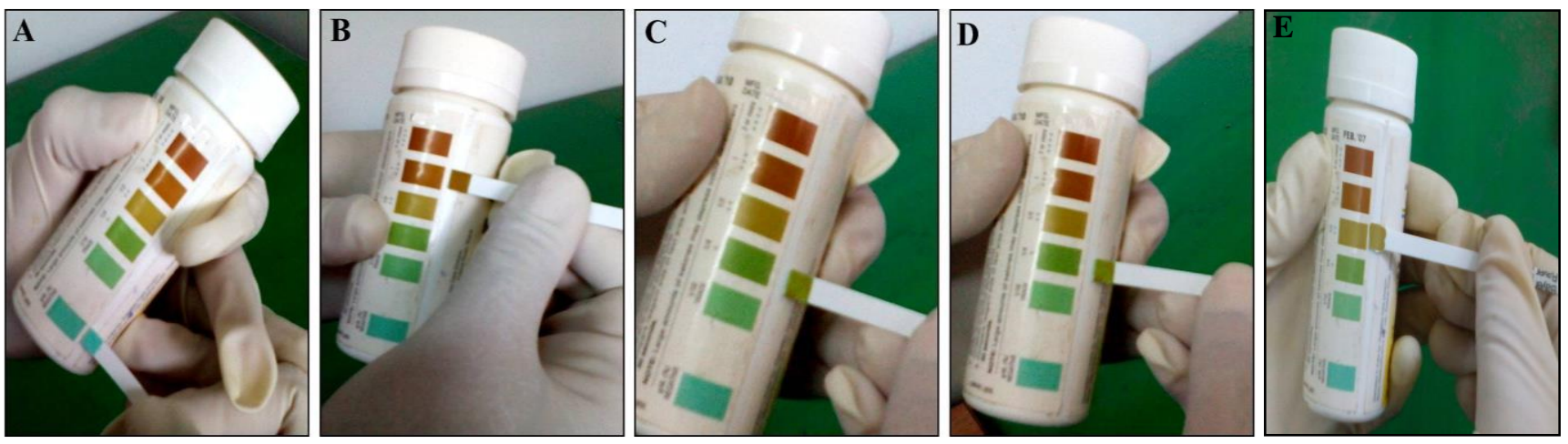

Figure 2: Above pictures are showing the glucose concentration in rat urine on $\mathbf{2 8}^{\text {th }}$ day of treatment with urine analysis glucose reagent strips. A, B, C represent the glucose analysis of untreated normal control, diabetic control, standard drug Glibenclamide $(10 \mathrm{mg} / \mathrm{kg})$ treated rats respectively, $D$ and $\mathrm{E}$ represent the urine analysis of test sample RME 200mg/kg and RMJ 200mg/kg (most effective dose) treated groups respectively.
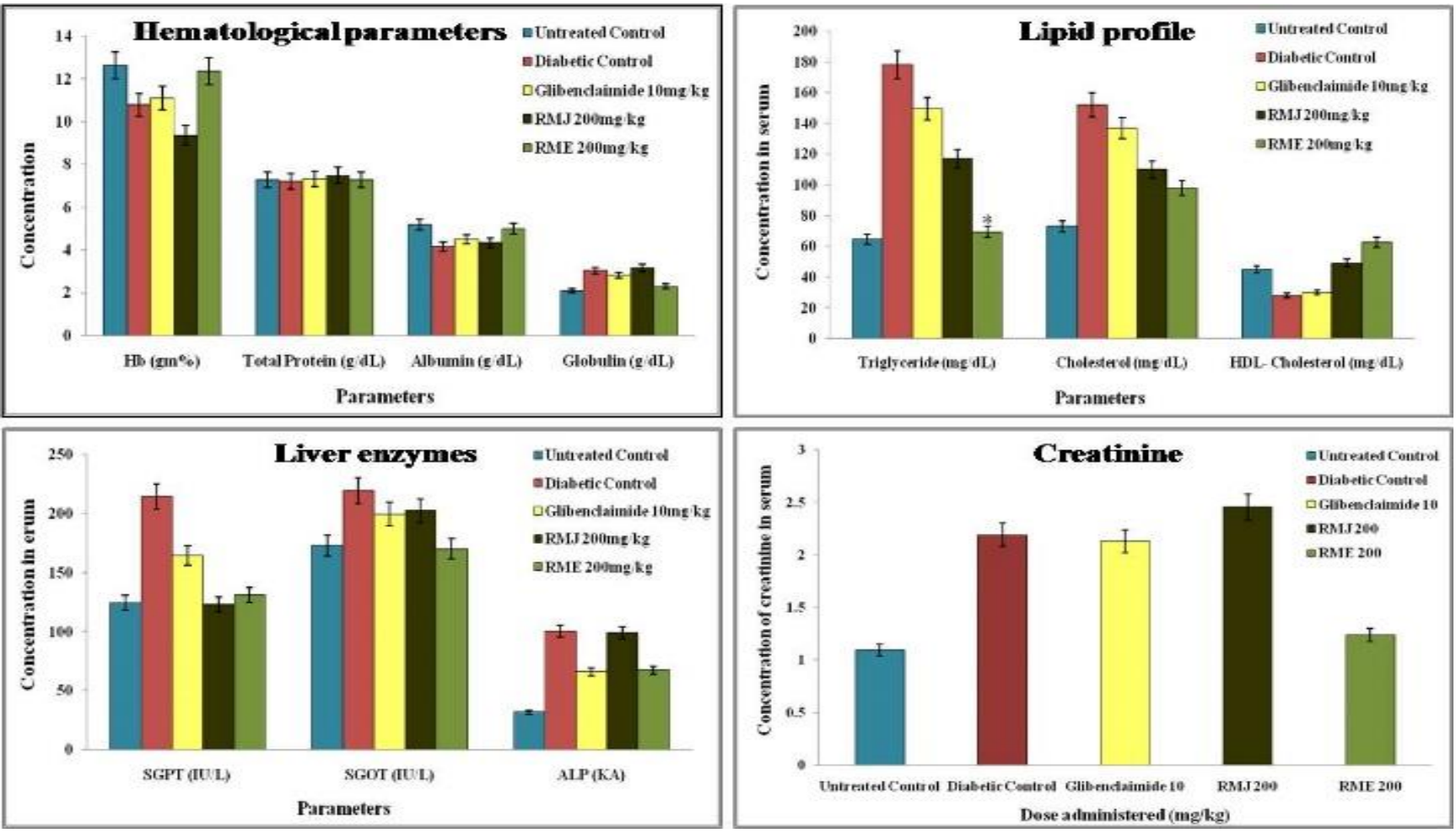

RME=ethanolic extract of Rhizophora mucronata leaves

$\mathrm{RMJ}=$ fresh juice of Rhizophora mucronata leaves

$*$ denotes $\mathrm{p}<0.05$.

Figure 3: The different biochemical parameters in rat serum on $28^{\text {th }}$ day in Streptozotocin induced diabetic model. Data was interpreted as Mean \pm S.E.M. Statistical analysis was done by one way ANOVA followed by Dunnett test.

\section{Biochemical parameters in serum}

The comparative analysis of the biochemical parameters in rat serum after 28 days treatment (Figure 3) showed that both the extract in the most effective dose $200 \mathrm{mg} / \mathrm{kg}$ decreased the elevated lipid levels and liver enzyme levels than the diabetic control group. After the treatment, the biochemical parameters of the treated group of rats were similar to that of the negative control group. There were no such changes in the hematological parameters but the extract improved the hemoglobin level in the treated rats maintain good health. Present study revealed that beside the potent blood sugar lowering, activity, ethanolic extract showed significant lipid lowering potentialities in Streptozotocin induced diabetic model among the two extracts. It also lowered the elevated creatinine level than the diabetic control and standard drug treated groups. 
Glibenclamide was also evaluated for any lipid lowering action in STZ induced diabetic rats. Another important finding was the both extracts enhanced the high density lipoprotein (HDL) -cholesterol, which is known to play an important role in the transport of cholesterol from peripheral cells to the liver and is considered to be a cardioprotective lipid.

\section{DISCUSSION}

Previous studies showed that, the fresh juice and the ethanolic extract of Rhizophora mucronata Lam. leaves even in the higher dose of $2 \mathrm{gm} / \mathrm{kg}$ body weight in rats did not show any toxic signs symptoms. ${ }^{9,10}$ Streptozotocin induced diabetic animals are most commonly used for screening the compounds such as natural compounds for its hypoglycaemic/anti-hyperglycaemic activities. ${ }^{15,16}$ Streptozotocin (STZ) is well known for its selective pancreatic islet beta cell cytotoxicity and has been extensively used to induce type 1 diabetes mellitus in animals. ${ }^{17,18}$ In the present study, a comparative analysis of the anti-diabetic action of fresh juice and ethanolic extract of leaves of Rhizophora mucronata was done in Streptozotocin diabetic model. The study with the fresh juice confirmed its efficacy as anti-hyperglycaemic and the ethanolic extract also distinctly decreased the elevated blood sugar in the treated group of rats. $200 \mathrm{mg} / \mathrm{kg}$ was the best dose for both the extracts. The ethanol extract in $100 \mathrm{mg} / \mathrm{kg}$ and $200 \mathrm{mg} / \mathrm{kg}$ doses revealed more significant anti-diabetic activity among the both extracts. The difference between the treated groups and diabetic control rats in lowering the fasting plasma glucose levels was significant. Research revealed, regular administration of the ethanolic extract of $R$. mucronata Lam. leaves for 4 weeks resulted in a significant diminution of blood glucose level with respect to STZ-diabetic rat, which clearly explains its anti-diabetic activity. ${ }^{19}$

Some recent studies also supported that hydro-alcoholic extract of $R$. mucronata leaves exhibited antiradical and anti-diabetic effects. ${ }^{12,13}$ A study from Bangladesh demonstrated that, the ethanol extracts of Rhizophora mucronata Poir leaves showed significant inhibition of carbohydrate digestion and absorption, which has resulted in hypoglycemic effects of Rhizophora mucronata. ${ }^{11}$ Present study also revealed that the ethanolic extract of $R$. mucronata leaves not only have anti-hyperglycemic action but also have lipid lowering action. It reduced total cholesterol, triglycerides and by- low density lipoprotein (LDL) compared to the diabetic control groups, also increased the HDL-cholesterol, which is an added benefit.

Hyperglycemia can stimulate ROS (Reactive Oxygen Species) production from a variety of sources. Phenolic phytochemicals act as preventive agents against oxidative damage. Theses have been in recent focus for decreasing the risk of developing chronic diseases by reducing oxidative stress and inhibiting macromolecular oxidation. ${ }^{20}$ Thus, prevention of oxidative damage with natural antioxidants is important diabetic prevention strategies. Literature survey revealed the antioxidative, antidiabetic and cardioprotective activities of phenols, flavonoids, and polysaccharides. Previous research also showed the ethanolic extract of $R$. mucronata Lam. leaves have promising antioxidant properties. $R$. mucronata leaves content rich amount of phenolic acids and flavonoids. ${ }^{21}$ Earlier studies also revealed the presence of Quercetin in the fresh leaves of $R$. mucronata juice..$^{10}$ It is also suggested that the polyphenols are widely distributed in the plant kingdom as secondary metabolites and are reported to possess antioxidant and anti-diabetic properties. ${ }^{22,23}$ Therefore, significant amount of phenolic acids and flavonoids in the leaf extract might be considered as the major phytoconstituents responsible for the antidiabetic action.

Present study explored the scientific relevance of the ethno-medicinal uses of Sunderban mangrove $R$. mucronata leaves in the treatment of diabetes. This may lead to therapeutic correlation of this mangrove in the treatment of diabetes and its complications.

\section{CONCLUSION}

In the present scenario, the management of diabetes mellitus is still a challenge to the researchers. Search for effective and safe alternative anti-diabetic agents is a need for the society because of the limitations of conventionally used synthetic anti-diabetic medicines. The World Health Organization (WHO) recommends the research on the uses of medicinal plants in the treatment of diabetes mellitus for their beneficial effects. Present study revealed the significant anti-hyperglycemic property of Rhizophora mucronata Lam. leaves, and the ethanolic extract of the leaves may be more beneficial because of having potent lipid lowering action along with anti-hyperglycemic property. Research is under process to identify the active molecule from Rhizophora mucronata Lam leaves, as an anti-hyperglycaemic agent with better efficacy and less toxicity.

\section{ACKNOWLEDGEMENTS}

The authors would like to express gratitude to the Principal, R. G. Kar Medical College, Kolkata for providing support in every aspect for conducting the study. Authors are immensely grateful to Department of Science and Technology (DST), Government of West Bengal for proving financial assistance for conducting the research work. Authors also acknowledge academic support from West Bengal University of Health Sciences, Kolkata in this research.

Funding: Funding sources from Department of Science and Technology (DST), Government of West Bengal Conflict of interest: None declared

Ethical approval: The study was approved by the Institutional Animal Ethics Committee of R. G. Kar Medical College, Kolkata (RKC/IAEC/13/17/1) 


\section{REFERENCES}

1. American Diabetes Association. Diagnosis and Classification of Diabetes Mellitus. Diabetes Care 2009;32(1):S62-7.

2. Rajaei Z, Hadjzadeh M, Moradi R, Ghorbani A, Saghebi A. Antihyperglycemic and antihyperlipidemic effects of hydroalcoholic extract of Securigera securidaca seeds in streptozotocin-induced diabetic rats. Adv Biomed Res. 2015;4:33.

3. Das SK, Samantaray D, Thatoi H. Ethnomedicinal, Antimicrobial and Antidiarrhoeal Studies on the Mangrove Plants of the Genus Xylocarpus: A Mini Review. J Bioanal Biomed. 2014;S12(004):1-7.

4. Bandaranayake WM. Bioactivities, bioactive compounds and chemical constituents of mangrove plants. Wetlands Ecol Mangt. 2002;10:421-52.

5. Duke JA, Wain KK. Medicinal plants of the World. Computer index with more than 85,000 entries. 1981;3:1654.

6. Ramanathan T, Hariharan B, Ganesan K. Antidiabetic activity of a coastal mangrove leaves of Rhizophora mucronata. Int J Plant Res: Plant Arch. 2008;8:931-3.

7. Pandey AK, Gupta PP, Lal VK. Hypoglycemic effect of Rhizophora mucronata in streptozotocin induced diabetic rats. J. Complement Integr Med. 2014;11:179-83.

8. Kumar S, Sandhir R, Ojha S. Evaluation of antioxidant activity and total phenol in different varieties of Lantana camara leaves. BMC Research Notes. 2014;7:560.

9. Adhikari A, Ray M, Sur TK, Kanjilal S, Roy RK, Das AK. Analgesic actions of Sunderban mangrove, Rhizophora mucronata L. leaves. Journal of Medicinal Plants Studies. 2016;4(3):140-3.

10. Ray M, Adhikari A, Sur TK, Mondal C, Pathak A, Das AK. Pharmacognostic and anti-hyperglycemic evaluation of the leaves of Sunderban mangrove, Rhizophora mucronata. Pharmanest. 2014;5:2289-94.

11. Gaffar MU, Morshed MA, Uddin A, Roy S, Hannan JMA. Study the efficacy of Rhizophora mucornata Poir. leaves for diabetes therapy in long evans rats. International Journal of Biomolecules and Biomedicine. 2011;1(1):20-6.

12. Sur TK, Hazra AK, Bhattacharyya D, Hazra A. Antiradical and antidiabetic properties of standardized extract of Sunderban mangrove Rhizophora mucronata. Phcog Mag. 2015;11:389-94.

13. Pandey AK, Gupta PP, Lal VK. Hypoglycemic effect of Rhizophora mucronata in streptozotocin induced diabetic rats. $\mathrm{J}$ Complement Integr Med. 2014;11(3):179-83.
14. Sur TK, Seal T, Pandit S, Bhattacharyya D. Hypoglycemic properties of a mangrove plant, Rhizophora apiculata Blume. Natural Product Sciences. 2004;10:11-5.

15. Akbarzadeh A, Norouzian D, Mehrabi MR, Jamshidi $\mathrm{SH}$, Farhangi A, Verdi AA, et al. Induction of diabetes by streptozotocin in rats. Indian Journal of Clinical Biochemistry. 2007 Sep 1;22(2):60-4.

16. Gandhi GR, Sasikumar P. Antidiabetic effect of Merremia emarginata Burm. F. in streptozotocin induced diabetic rats. Asian Pac J Trop Biomed. 2012;2(4):281-6.

17. Kumar S, Kumar V, Prakash O. Antidiabetic and antilipemic effects of Cassia siamea leaves extract in streptozotocin induced diabetic rats. Asian Pac J Trop Med. 2010;3:871-3.

18. Wu J, Yan L. Streptozotocin-induced type 1 diabetes in rodents as a model for studying mitochondrial mechanisms of diabetic $\beta$ cell glucotoxicity. Diabetes Metab Syndr Obes. 2015;8:181-8.

19. Ray M, Adhikari A, Sur TK, Biswas S, Roy RK, Das AK. Promising Blood Sugar Lowering Action of Sunderban Mangrove. Indian J Pharmacol. 2014;46(1):S62-113.

20. Wang Y, Xiang L, Wang C, Tang C, He X. Antidiabetic and antioxidant effects and phytochemicals of mulberry fruit (Morus alba L.) polyphenol enhanced extract. Plos One. 2013;8:e71144.

21. Ray M, Adhikari A, Sur TK, Besra SE, Biswas S, Das AK. Evaluation of Anti-Inflammatory Potential of Ethanolic Extract of the Leaves of Rhizophora Mucronata, a Sunderban Mangrove. Int J Res Dev Pharm L Sci. 2017;6(2):2510-1.

22. Vessal M, Hemmati M, Vasei M. Antidiabetic effects of quercetin in streptozocin-induced diabetic rats. Comparative Biochem Physiol C. 2003;135:357-64.

23. Abdelmoaty MA, Ibrahim MA, Ahmed NS, Abdelaziz MA. Confirmatory studies on the antioxidant and antidiabetic effect of quercetin in rats. Indian Journal of Clinical Biochemistry. 2010;25(2):188-92.

Cite this article as: Adhikari A, Ray M, Sur TK, Biswas S, Das AK. Comparative evaluation of antidiabetic activity of fresh juice and ethanolic extract of Sunderban mangrove Rhizophora mucronata Lam. leaves in animal model. Int J Basic Clin Pharmacol 2017;6:2193-8. 